\title{
Antiplatelet Aggregation and Antithrombosis Efficiency of Peptides in the Snake Venom of Deinagkistrodon acutus: Isolation, Identification, and Evaluation
}

\author{
Bin Ding, Zhenghong Xu, Chaodong Qian, Fusheng Jiang, Xinghong Ding, \\ Yeping Ruan, Zhishan Ding, and Yongsheng Fan
}

Zhejiang Chinese Medical University, Hangzhou, Zhejiang 310053, China

Correspondence should be addressed to Yongsheng Fan; applezjtcm@126.com

Received 25 July 2015; Accepted 3 September 2015

Academic Editor: Settimio Grimaldi

Copyright (c) 2015 Bin Ding et al. This is an open access article distributed under the Creative Commons Attribution License, which permits unrestricted use, distribution, and reproduction in any medium, provided the original work is properly cited.

\begin{abstract}
Two peptides of Pt-A (Glu-Asn-Trp $429 \mathrm{Da}$ ) and Pt-B (Glu-Gln-Trp $443 \mathrm{Da}$ ) were isolated from venom liquor of Deinagkistrodon acutus. Their antiplatelet aggregation effects were evaluated with platelet-rich human plasma in vitro; the respective $\mathrm{IC}_{50}$ of $\mathrm{Pt}$ A and Pt-B was $66 \mu \mathrm{M}$ and $203 \mu \mathrm{M}$. Both peptides exhibited protection effects on ADP-induced paralysis in mice. After ADP administration, the paralysis time of different concentration of Pt-A and Pt-B lasted as the following: $80 \mathrm{mg} / \mathrm{kg} \mathrm{Pt}-\mathrm{B}$ (152.8 $\pm 57.8 \mathrm{~s}$ ) $<40 \mathrm{mg} / \mathrm{kg}$ Pt-A $(163.5 \pm 59.8 \mathrm{~s})<20 \mathrm{mg} / \mathrm{kg}$ Pt-A $(253.5 \pm 74.5 \mathrm{~s})<4 \mathrm{mg} / \mathrm{kg}$ clopidogrel (a positive control, $254.5 \pm 41.97 \mathrm{~s})<$ $40 \mathrm{mg} / \mathrm{kg} \mathrm{Pt}-\mathrm{B}(400.8 \pm 35.9 \mathrm{~s})<10 \mathrm{mg} / \mathrm{kg}$ Pt-A $(422.8 \pm 55.4 \mathrm{~s})$, all of which were statistically shorter than the saline treatment (666 $\pm 28 \mathrm{~s}$ ). Pulmonary tissue biopsy confirmed that Pt-A and Pt-B prevented the formation of thrombi in the lung. Unlike ADP injection alone, which caused significant reduction of peripheral platelet count, Pt-A treatment prevented the drop of peripheral platelet counts; interestingly, Pt-B could not, even though the same amount of Pt-B also showed protection effects on ADP-induced paralysis and thrombosis. More importantly, intravenous injection of Pt-A and Pt-B did not significantly increase the hemorrhage risks as clopidogrel.
\end{abstract}

\section{Introduction}

Thrombosis, associated with blood coagulation, is one of the important factors leading to cardiovascular diseases (CVD), the major cause of death worldwide [1]. Antithrombosis therapies, such as aspirin and clopidogrel in clinical practice, have contributed to dramatic improvements of patient survival, but such drugs often increase hemorrhage risks in patients [2].

In China, snake wine or snake venom liquor, prepared by infusing whole snake or its venom into grain alcohol for months, is supplied as a traditional Chinese medicine (TCM) for CVD prevention and rehabilitation [3, 4]. These kinds of liquor are used widely in Asian countries, such as Cambodia, China, Japan, Korea, Laos, Thailand, and Vietnam [5, 6]. Clinical practice suggests that the venom liquor could help patients rehabilitate from hemiplegic stroke, cervical spondylosis, scapulohumeral periarthritis, lumbar, arthritis, rheumatism, breast hyperplasia, and gout without any adverse effects [3]. Numerous modern studies have illuminated that a few specific proteins, oligopeptides, and polypeptides, in the venom present the antithrombosis and antiplatelet aggregation activities [7].

Deinagkistrodon acutus, a specific venomous snake in China, is commonly used to prepare medicinal liquor [3] documented in the book Master Lei's Discourse on Drug Processing (Leigong Pao Jiu Lun) initially. As described, D. acutus liquor could achieve the patency of blood flow and meridians. However, little is known on what the venom liquor consists of and how does it function. We hypothesize that peptides are the key components for the clinical effect of the venom liquor. In the current study, two oligopeptides were isolated from the venom liquor and sequenced. Their antiplatelet aggregation and antithrombosis efficiency were examined in vitro and in vivo. Our results suggest that Pt$\mathrm{A}$ and $\mathrm{Pt}-\mathrm{B}$ can prevent platelet aggregation via different mechanisms. 


\section{Materials and Methods}

2.1. Materials. Lyophilized venom of D. acutus was provided by Taizhou Snake Farm (Zhejiang, China) and kept in refrigerator at $-20^{\circ} \mathrm{C}$. ICR mice, 18 weeks of age and 23-25 g of weight, were obtained from Laboratory Animal Center of Zhejiang Chinese Medical University (Hangzhou, China). ADP was purchased from Sigma-Aldrich (St. Louis, MO, USA); clopidogrel hydrogen sulphate tablets were from Sanofi Winthrop Industrie (Paris, France). Acetonitrile and trifluoroacetic acid (HPLC grade) were from Anaqua Chemicals Supply Inc. Limited (Houston, USA). Other chemical reagents were from China National Pharmaceutical Group Corporation (Shanghai, China). Distilled water was produced by an automatic pure water distillation (Shanghai Yarong Biochemical Instrument Company, Shanghai, China). The AKTA Explorer 10 FPLC was from GE-Amersham Pharmacia Biotech (Piscataway, USA) and Sephadex G50 was from Pharmacia (Uppsala, Sweden). The Dionex UltiMate 3000 high performance liquid chromatography system and a Dionex Acclaim $120 \mathrm{C}_{18}$ column $(250 \times 10 \mathrm{~mm}$, $2.2 \mu \mathrm{m})$ were purchased from Thermo Fisher Scientific Inc. (Sunnyvale, USA). AggRAM aggregometer, Sysmex XS-500i Analyzer, SpectraMax M3 Multimode Microplate Reader, and Q-TOF 2 mass spectrometer with MassLynx NT were from Helena Laboratories (Texas, USA), Sysmex Corporation (Kobe, Japan), Molecular Devices, Inc. (Sunnyvale, USA), and Micromass UK Ltd. (Altrincham, UK), respectively. The Pt-A and Pt-B peptides were synthesized by Shanghai Ketai Bio-Science and Technology Co. Ltd. (Shanghai, China).

2.2. Preparation of Snake Venom Liquor. $500 \mathrm{mg}$ venom was infused in $1 \mathrm{~L} 60 \%$ ethanol for 3 months at room temperature. The liquor was centrifuged at $12,000 \mathrm{~g}$ for $30 \mathrm{~min}$ at $4^{\circ} \mathrm{C}$. The debris was washed with $300 \mathrm{~mL} \mathrm{60 \%} \mathrm{ethanol} \mathrm{and} \mathrm{discarded;}$ the supernatants were pooled and lyophilized at $60^{\circ} \mathrm{C}$.

2.3. Isolation and Identification of the Two Peptides. The lyophilized material was resuspended with distilled demineralized water $\left(\mathrm{ddH}_{2} \mathrm{O}\right)$ and applied to a water-equilibrated Sephadex G-50 column $(38 \mathrm{~cm} \times 1.6 \mathrm{~cm})$ of the AKTA Explorer FPLC and monitored at $215 \mathrm{~nm}$. The target peptides were eluted together with $\mathrm{ddH}_{2} \mathrm{O}$ at room temperature with the flow rate of $2 \mathrm{~mL} / \mathrm{min}$. This eluent was applied to semipreparative RP-HPLC, monitored at $215 \mathrm{~nm}$, on an Acclaim $120 \mathrm{C}_{18}$ column $(250 \times 10 \mathrm{~mm})$ equilibrated with buffer A (5\% acetonitrile containing $0.1 \%$ trifluoroacetic acid). The two peptides were eluted and separated with an acetonitrile gradient with its concentrations changed from 5\% in buffer $\mathrm{A}$ to $35 \%$ in buffer B (35\% acetonitrile containing $0.1 \%$ trifluoroacetic acid) in $30 \mathrm{~min}$. The column temperature was kept at $30^{\circ} \mathrm{C}$. The amino acid sequence of peptides was identified with Q-TOF mass spectrometer and NMR in comparison with standards $[8,9]$.

2.4. Antiplatelet Aggregation Activity In Vitro. The antiplatelet activity of Pt-A and Pt-B was evaluated in ADP-induced platelet aggregation assays described by Born [10]. The venous blood was from healthy volunteers free from aspirin or other nonsteroidal anti-inflammatory drugs for more than 7 days and kept in citrated tubes. The platelets were precipitated by centrifugation at $200 \times \mathrm{g}$ for $8 \mathrm{~min}$ and resuspended in platelet poor serum, resulting in a final concentration of $2.5-3.0 \times 10^{8}$ cells $/ \mathrm{mL}$. $250 \mu \mathrm{L}$ venous blood was incubated with $10 \mu \mathrm{L} 0.008,0.086,0.175,0.258,0.347,0.508$, and $0.75 \mathrm{mM}$ Pt-A saline solution or $0.028,0.083,0.166,0.250$, $0.416,0.583$, and $0.72 \mathrm{mM}$ Pt-B saline solution, respectively, at $37^{\circ} \mathrm{C}$ for 5 minutes. $5 \mu \mathrm{L} 5 \mu \mathrm{M}$ ADP was pipetted into the reaction and the maximal aggregation of platelets was monitored with Helena Platelet Aggregation Analyzer in 5 minutes. The assays were performed in triplicate and the efficiency was present as median lethal dose $\left(\mathrm{IC}_{50}\right)$.

2.5. Protection Efficiency of Pt-A and Pt-B on ADP-Induced Pulmonary Thromboembolism in Mice. 64 male ICR mice (18 months old, 23-25 g) were randomly divided into 8 groups. These mice were pretreated with intravenous injection of $\mathrm{Pt}-\mathrm{A}$ $(10,20$, or $40 \mathrm{mg} / \mathrm{kg}), \mathrm{Pt}-\mathrm{B}(20,40$, or $80 \mathrm{mg} / \mathrm{kg})$, clopidogrel ( $4 \mathrm{mg} / \mathrm{kg}$, as a positive control), or saline solution (as a negative control) in tail vein. Fifteen minutes later, the mice were paralyzed by intravenous injection of ADP $(200 \mathrm{mg} / \mathrm{kg})$. The time when the mice come back to movement was recorded as the paralysis time, and it was compared and analyzed statistically $[11,12]$. Another 63 male ICR mice (18 months old, 23-25 g) were divided into 7 groups (without clopidogrel group) and treated as described above again. The peripheral blood was collected 1 minute after ADP administration for platelet counting with Sysmex XS-500i Hematology Analyzer. Meanwhile, the lung was fixed in $10 \%$ formalin. The paraffinembedded sections of lungs were stained with hematoxylineosin staining and observed under microscope [13].

2.6. Haemorrhage Test. The haemorrhage efficiency of the two peptides was identified with a modified tail cutting method [14]. Male ICR mice were randomly grouped with 7 mice in each group and preprotected with Pt-A $(40 \mathrm{mg} / \mathrm{kg})$, Pt-B (40 mg/kg), clopidogrel (4 mg/kg), or saline (as a control) by tail vein injection, 15 minutes (clopidogrel was $2 \mathrm{~h}$ ) before tail cutting. The tails of mice that were anesthetized with pentobarbital sodium $(100 \mathrm{mg} / \mathrm{kg})$ were transected $5 \mathrm{~mm}$ from the tip and stretched into $12 \mathrm{~mL}$ saline for 10 minutes at $37^{\circ} \mathrm{C}$. The same volume red blood cell lysis buffer $\left(15 \mathrm{mM} \mathrm{NH}_{4} \mathrm{Cl}, 10 \mathrm{mM} \mathrm{KHCO}_{3}\right.$, and $0.1 \mathrm{mM} \mathrm{Na}_{2}$ EDTA [disodium ethylenediamine tetraacetate], $\mathrm{pH}=7.3$ ) was added and mixed well. Meanwhile, a group of standard mixtures were prepared. The absorbance of these solutions was estimated at $490 \mathrm{~nm}$ and the blood volumes were calculated with standard curve $[15,16]$.

2.7. Statistical Analysis. Results were presented as means $\pm \mathrm{SD}$ obtained from the indicated number of animals or samples. The statistical analysis was performed by GraphPad Prism 5.00, using unpaired Student's $t$-test.

\section{Results}

3.1. Purification and Identification of Pt-A and Pt-B. Pt-A and $\mathrm{Pt}-\mathrm{B}$ were purified with two chromatographical steps; their yields from $0.5 \mathrm{~g}$ venom were $1 \mathrm{mg} / \mathrm{g}$ and $11 \mathrm{mg} / \mathrm{g}$, 


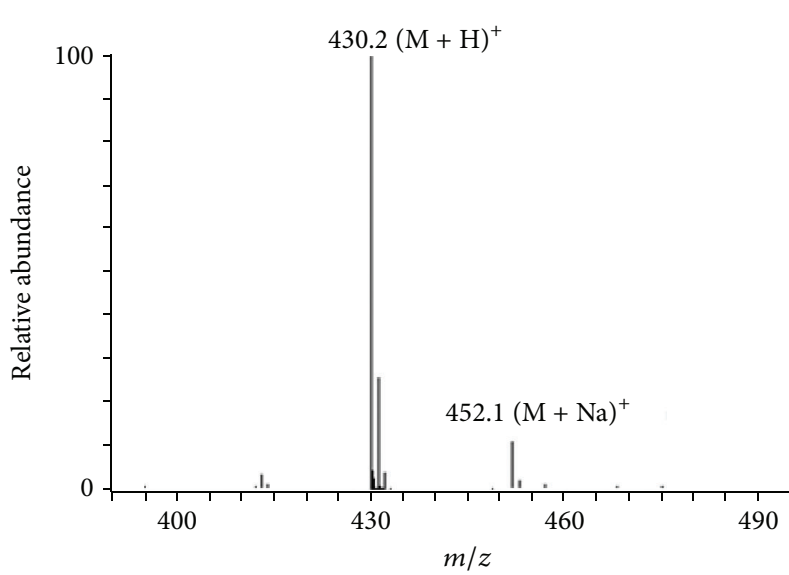

(a)

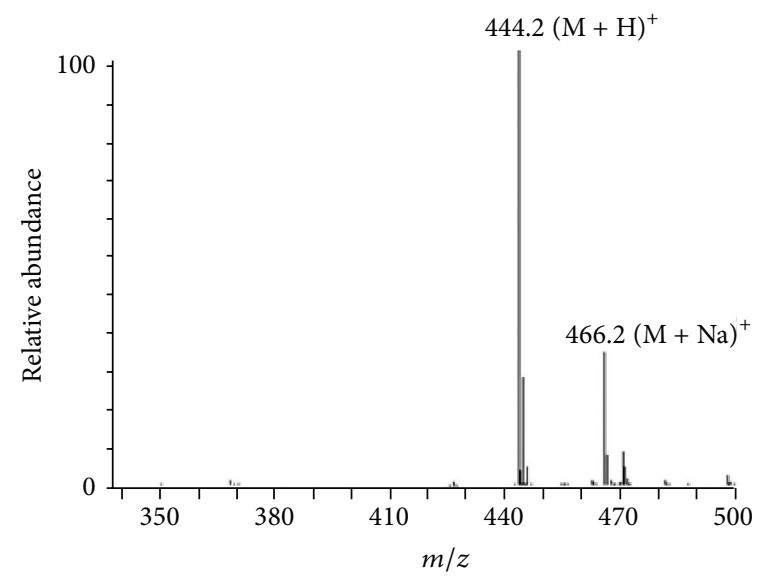

(b)<smiles>NC(=O)CC(NC(=O)C1CCC(=O)N1)C(=O)NC(Cc1c[nH]c2ccccc12)C(=O)O</smiles>

pyroGlu-Asn-Trp (Pt-A)

(c)<smiles>NC(=O)CCC(NC(=O)C1CCC(=O)N1)C(=O)NC(Cc1c[nH]c2ccccc12)C(=O)O</smiles>

pyroGlu-Gln-Trp (Pt-B)

(d)

Figure 1: Q-TOF mass spectra of HPLC separated Pt-A (a) and Pt-B (b). The molecular masses of Pt-A and Pt-B were 429 Da (a) and 443 Da (b), as identified with Q-TOF mass analysis. The amino acid sequence of Pt-A (c) and Pt-B (d) was identified through comparing their Q-TOF spectra to those of synthesized tripeptides (positive controls were not shown).

separately. The water-soluble fraction in snake venom liquor was $0.232 \mathrm{~g}$ and in the Sephadex G-50 eluent was $17.95 \mathrm{mg}$. The retention times of purified Pt-A and Pt-B were identified to those of synthesized oligopeptides pyroglutamateasparagine-tryptophan (PAT) and pyroglutamate-glutaminetryptophan (PGT), respectively (results not shown). And, based on ion peaks at $m / z 430.2\left([\mathrm{M}+\mathrm{H}]^{+}\right)$and $444.2([\mathrm{M}+$ $\mathrm{H}]^{+}$), the molecular masses of Pt-A and Pt-B (Figure 1) were determined to be $429 \mathrm{Da}$ and $443 \mathrm{Da}$, which were identified to those of synthesized PAT and PGT, also.

3.2. Antiplatelet Aggregation Efficiency In Vitro. The antihuman platelet aggregation activity of the two tripeptides, in a dose-dependent manner, was shown in Figure 2. Both $\mathrm{Pt}-\mathrm{A}$ and $\mathrm{Pt}-\mathrm{B}$ inhibited platelet aggregation in the in vitro experiment, but Pt-A had a stronger effect than Pt-B. $\mathrm{IC}_{50}$ of $\mathrm{Pt}-\mathrm{A}$ and Pt-B was $0.066 \mathrm{mM}$ and $0.203 \mathrm{mM}$, respectively.

3.3. Protection Efficiency of Pt-A and Pt-B on ADP-Induced Thrombosis Mice Model. The ADP-induced thrombosis in mice was one of the most used animal models for antithrombotic agent evaluation with indicators including the paralysis in the animals, reduction of free platelet cells in the blood, and the presence of micro-thrombi in the lung. In the current study, ADP paralyzed the mice in the saline group for 666 \pm 28 seconds (mean $\pm \mathrm{SD}$ ). In comparison, the paralysis time of Pt-A at the doses of 10, 20, and $40 \mathrm{mg} / \mathrm{kg}$ and Pt$\mathrm{B}$ at the doses of 40 and $80 \mathrm{mg} / \mathrm{kg}$ groups lasted for 422.8 $\pm 55.4,253.5 \pm 74.5,163.5 \pm 59.8,400.8 \pm 35.9$, and 152.8 \pm 57.8 seconds, respectively, all of which were statistically significantly shorter compared with the time in the saline group $(P<0.01)$. Simultaneously, the mice of clopidogrel ( $4 \mathrm{mg} / \mathrm{kg}$ ) group, a positive control, were paralyzed for 254.5 \pm 41.97 seconds. However, the paralysis time of $20 \mathrm{mg} / \mathrm{kg}$ Pt-B group was $592.8 \pm 67.9$ seconds, showing no difference from the saline group $(P>0.05)$. This suggested that pretreatment with Pt-A $(10,20$, and $40 \mathrm{mg} / \mathrm{kg})$ and Pt-B $(40,80 \mathrm{mg} / \mathrm{kg})$ protected mice from ADP-induced paralysis significantly (Figure 3).

When the mice in the control group were pretreated with saline and injected with saline 15 minutes later, the mean count of their platelets was $1.00 \times 10^{6} / \mu \mathrm{L}$. Injection of ADP after saline pretreatment (the paralysis group) significantly decreased the peripheral platelet count to $0.45 \times 10^{6} / \mu \mathrm{L}$. In contrast, pretreatment with 10,20 , and $40 \mathrm{mg} / \mathrm{kg}$ Pt-A kept the platelet counts to $0.87 \times 10^{6}, 1.03 \times 10^{6}$, and $0.96 \times$ $10^{6} / \mu \mathrm{L}$, similar levels to the control group. Interestingly, even though 40 and $80 \mathrm{mg} / \mathrm{kg}$ Pt-B pretreatment presented similar protection effects on the ADP-induced paralysis as $10 \mathrm{mg} / \mathrm{kg}$ and $40 \mathrm{mg} / \mathrm{kg}$ Pt-A, such amounts of Pt-B could not prevent the ADP-induced reduction of platelet counts $\left(0.514 \times 10^{6}\right.$ and $0.69 \times 10^{6} / \mu \mathrm{L}$, resp.) (Table 1$)$. Our results demonstrated that 
TABLE 1: The platelet counts in mice blood $\left(\times 10^{6} / \mathrm{mL}\right)$.

\begin{tabular}{|c|c|c|c|c|c|c|c|c|}
\hline & $\begin{array}{l}\text { Control } \\
\text { group }\end{array}$ & $\begin{array}{c}\text { ADP-induced } \\
\text { group }\end{array}$ & $\begin{array}{c}\text { Pt-A } \\
(10 \mathrm{mg} / \mathrm{kg})\end{array}$ & $\begin{array}{c}\text { Pt-A } \\
(20 \mathrm{mg} / \mathrm{kg}) \\
\end{array}$ & $\begin{array}{c}\text { Pt-A } \\
(40 \mathrm{mg} / \mathrm{kg})\end{array}$ & $\begin{array}{c}\text { Pt-B } \\
(20 \mathrm{mg} / \mathrm{kg}) \\
\end{array}$ & $\begin{array}{c}\text { Pt-B } \\
(40 \mathrm{mg} / \mathrm{kg}) \\
\end{array}$ & $\begin{array}{c}\text { Pt-B } \\
(80 \mathrm{mg} / \mathrm{kg})\end{array}$ \\
\hline Mean \pm SD & $1003 \pm 123.3$ & $454.3 \pm 90.21$ & $868.7 \pm 146.8$ & $1032 \pm 123.4$ & $959 \pm 89.9$ & $489.6 \pm 121.8$ & $514.6 \pm 97.16$ & $690.1 \pm 132.6$ \\
\hline $\begin{array}{l}P \text { (versus } \\
\text { control } \\
\text { group) }\end{array}$ & & ${ }^{*} P<0.01$ & $P>0.05$ & $P>0.05$ & $P>0.05$ & ${ }^{*} P<0.01$ & ${ }^{*} P<0.01$ & ${ }^{*} P<0.01$ \\
\hline
\end{tabular}

The peripheral platelets were counted with Sysmex XS-500i Hematology Analyzer after ADP injection. Values were presented as mean \pm SD with $n=8$ of each group. The data were analyzed by unpaired Student's $t$-test. If $P<0.05$, it was regarded as significant. The significant one was marked with “*”.

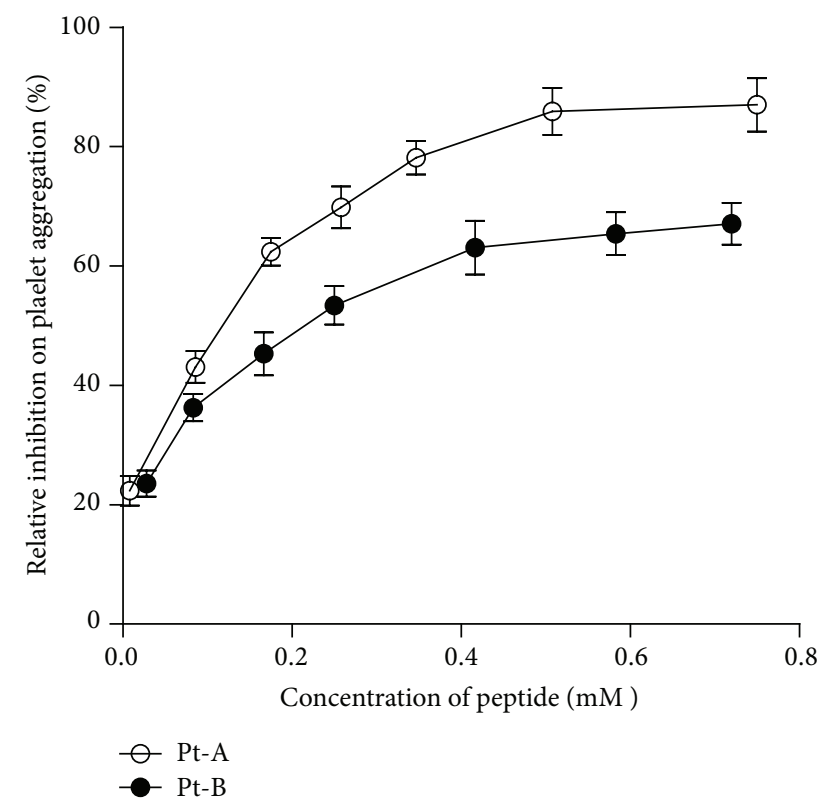

Figure 2: Relative inhibitory efficiency of Pt-A and Pt-B on ADPinduced platelet aggregation. The platelets were preincubated with Pt-A, Pt-B, or saline at $37^{\circ} \mathrm{C}$ for $5 \mathrm{~min}$ first. Platelet aggregation was initiated with $5 \mu \mathrm{M}$ ADP and monitored with Platelet Aggregation Analyzer. The relative inhibitory efficiencies of various concentrations of Pt-A (empty circles) and Pt-B (solid circles) were normalized with the saline group and presented as the mean $\pm \mathrm{SD}(n=3)$.

only Pt-A presented significant protection effects to the ADPinduced reduction of platelets $(P>0.05)$.

Next, we observed the formation of micro-thrombi under microscope in the lung from the same experiment (Figure 4). The homogeneous structure micro-thrombi, stained with hematoxylin-eosin staining in pink (marked with arrows), could be only observed in the paralysis control group (Figure 4(b)) but not in the negative control (Figure 4(a)), $40 \mathrm{mg} / \mathrm{kg}$ Pt-A (Figure 4(c)), and $40 \mathrm{mg} / \mathrm{kg}$ Pt-B (Figure 4(d)) groups.

3.4. Potential Haemorrhage Risk. An increased bleeding risk is mostly associated with antiplatelet aggregation and antithrombosis agents, for example, clopidogrel. To assess the bleeding risk, the loss of blood in Pt-A, Pt-B, clopidogrel, and saline (control) pretreated groups was in comparison measured (Figure 5). As expected, mice in the clopidogrel

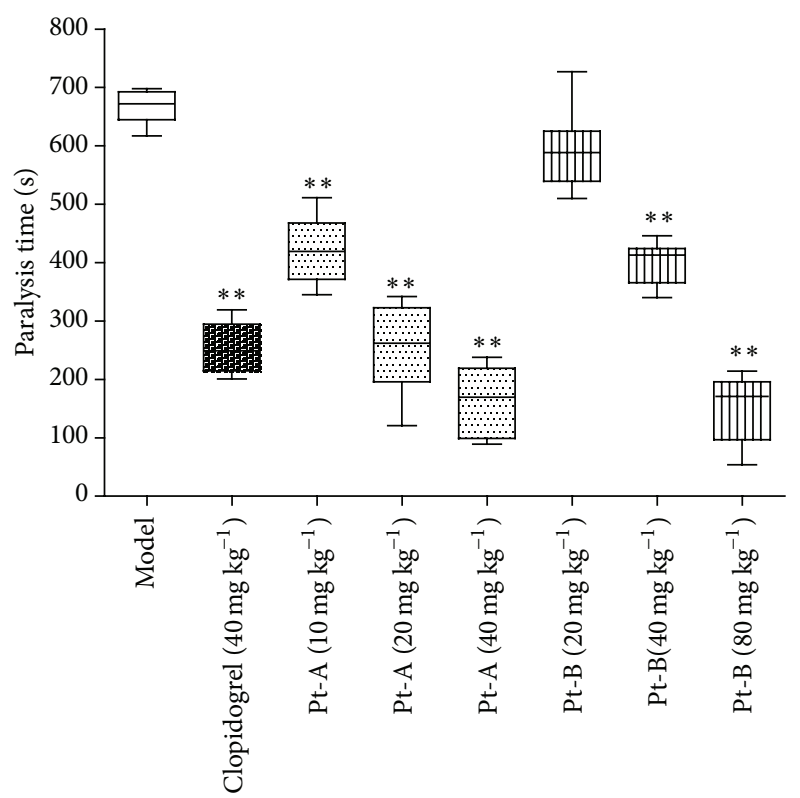

Figure 3: Effects of Pt-A and Pt-B on paralysis that was induced by ADP in mice. The mice in each group were injected intravenously (IV) with the following: saline; clopidogrel $\left(40 \mathrm{mg} \mathrm{kg}^{-1}\right)$, a positive control; Pt-A (10 mg kg${ }^{-1}, 20 \mathrm{mg} \mathrm{kg}^{-1}$, and $40 \mathrm{mg} \mathrm{kg}^{-1}$ ) and PtB $\left(20 \mathrm{mg} \mathrm{kg}^{-1}, 40 \mathrm{mg} \mathrm{kg}^{-1}\right.$, and $\left.80 \mathrm{mg} \mathrm{kg}^{-1}\right)$. After $15 \mathrm{~min}$, ADP $\left(200 \mathrm{mg} \mathrm{kg}^{-1}\right.$ ) was IV injected to induce paralysis. The time that the mice come back to move was recorded as the paralysis time, which was presented as the mean $\pm \mathrm{SD}$. All the data were compared to the saline group and analyzed by unpaired Student's $t$-test. ${ }^{* *} P<0.01$.

group lost more blood than those in the control (570.1 $\pm 237 \mu \mathrm{L}$ versus $211.1 \pm 168 \mu \mathrm{L} ; P<0.01)$. However, no significant difference of bleeding volume was observed between the two peptides groups $(40 \mathrm{mg} / \mathrm{kg}$ ) and the control (Pt-A $227.6 \pm 156.8 \mu \mathrm{L}$ versus $211.1 \pm 168 \mu \mathrm{L}$, Pt-B $166.9 \pm$ $103.5 \mu \mathrm{L}$ versus $211.1 \pm 168 \mu \mathrm{L} ;(P>0.05))$. This suggested that applying of Pt-A and Pt-B $(40 \mathrm{mg} / \mathrm{kg})$ to protect ADPinduced pulmonary thrombosis reduced the risk of bleeding in mice.

\section{Discussion}

Snake, the symbol of guilds of medicine and pharmacy in Europe, implied restoration of the health from sickness and bringing the dead back to life. Across China, as well as other Asian countries, snake and snake venom are recognized as 


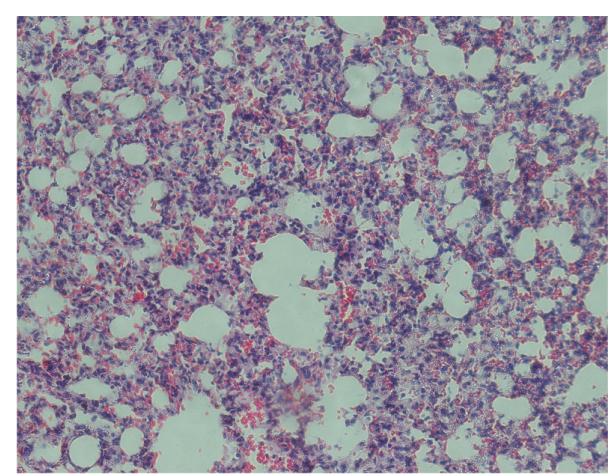

(a)

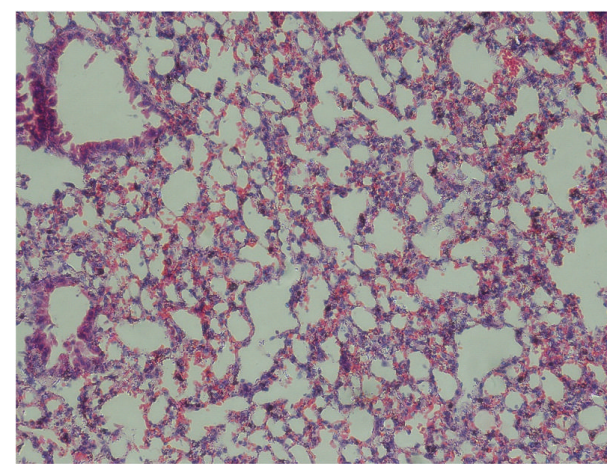

(c)

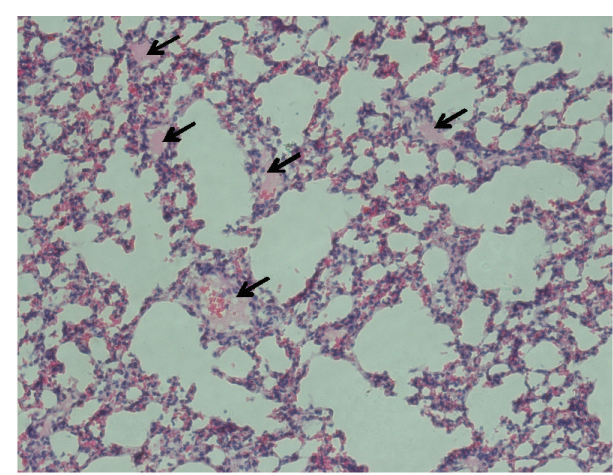

(b)

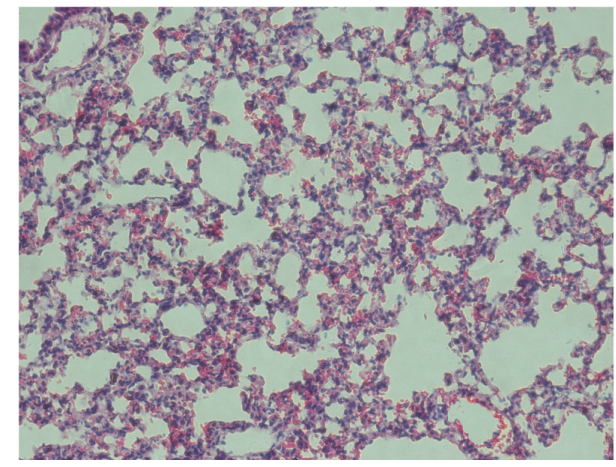

(d)

Figure 4: Protection effect of Pt-A and Pt-B on the ADP-induced formation of acute pulmonary thromboembolism in mice. The microthrombi (arrow) in the lung of (a) clopidogrel, (c) Pt-A $40 \mathrm{mg} \mathrm{kg}^{-1}$, (d) Pt-B $40 \mathrm{mg} \mathrm{kg}^{-1}$, or (b) saline pretreated mice were photographed (magnification $\times 20)$.

a traditional medicine. The main components of venom are proteins and peptides. The clinical significance of its different components is diverse and sometimes even they contradict each other, but as a whole they work fast and synergistically [17]. The multiple facets and functions of snake venom make its components so valuable for medicine.

Deinagkistrodon acutus, a specific genus of Viperidae family in Southeast Asia, produces and secretes lethal venom. The venom liquor exhibits significant clinical effect on CVD [3]. In present study, we isolated Pt-A (pGlu-AsnTrp) and Pt-B (pGlu-Gln-Trp) from the D. acutus venom liquor and demonstrated the antiplatelet aggregation and antithrombosis effects of them. In previous studies, Pt-A was found in Bungarus (1973) [18], Bothrops asper (1993) [19], and two Trimeresurus species (1993, 1998) [20, 21]. Henceforth, another two highly homogenetic peptides, GluGln-Trp (Pt-B) and Glu-Lys-Trp (pEKW), have been isolated simultaneously. In 2009, Pt-A was isolated from D. acutus venom for the first time by Kong et al. [9]. But no trace of Pt-B was observed in this species. To the best of our knowledge, it is the first study to illuminate Pt-B in D. acutus venom. However no trace of pEKW was observed in our research.

Even though Pt-A and Pt-B were discovered for years (1966), little of their potential clinical characters were studied. Majority of studies focused on the multiple metalloproteinases inhibitory effect of Pt-A and Pt-B $[19,21]$. The platelet aggregation inhibitory activity of $\mathrm{Pt}-\mathrm{A}$ on rabbit in vitro was demonstrated initially by Xiong et al. [14], with $\mathrm{IC}_{50}$ of $178 \mu \mathrm{M}$. To our surprise, $\mathrm{IC}_{50}$ of Pt-A on anti-human platelet aggregation was $66 \mu \mathrm{M}$ in vitro, much more efficient than that of Pt-B $\left(\mathrm{IC}_{50}=203 \mu \mathrm{M}\right)$. In addition, Pt-A exerted significant anti-ADP-induced platelet aggregation activity in vivo and Pt-B did not (Table 1). Surprisingly, Pt-B as well as Pt-A and clopidogrel could protect mice from ADP-stimulated paralysis (Figure 2) and the generation of microvascular thrombosis in the lung (Figure 3). It is not clear how Pt-B achieved its protection function against ADP-induced paralysis without exhibiting antiplatelet aggregation activity in vivo. We speculate that $\mathrm{Pt}-\mathrm{B}$ takes its antithrombosis function via a different mechanism from Pt-A. The antiplatelet aggregation and antithrombosis function of Pt-A were consistent with the research conclusion of Pt-A in the arteriovenous shunt models and inferior vena ligation models [9].

Besides, the hemorrhagic risks of Pt-A and Pt-B were compared with clopidogrel in a modified haemorrhage assay. The bleeding volumes in the two tripeptides pretreated groups were comparable to the saline group. On the contrary, the mice in the clopidogrel group lost more blood (Figure 5). This result demonstrates that Pt-A and Pt-B can prohibit platelet aggregation and thrombus formation without increasing the hemorrhagic risks.

To conclude, this study suggests that Pt-A and Pt-B are the bioactive components in the snake venom liquor of Deinagkistrodon acutus that contributed to cardiovascular 


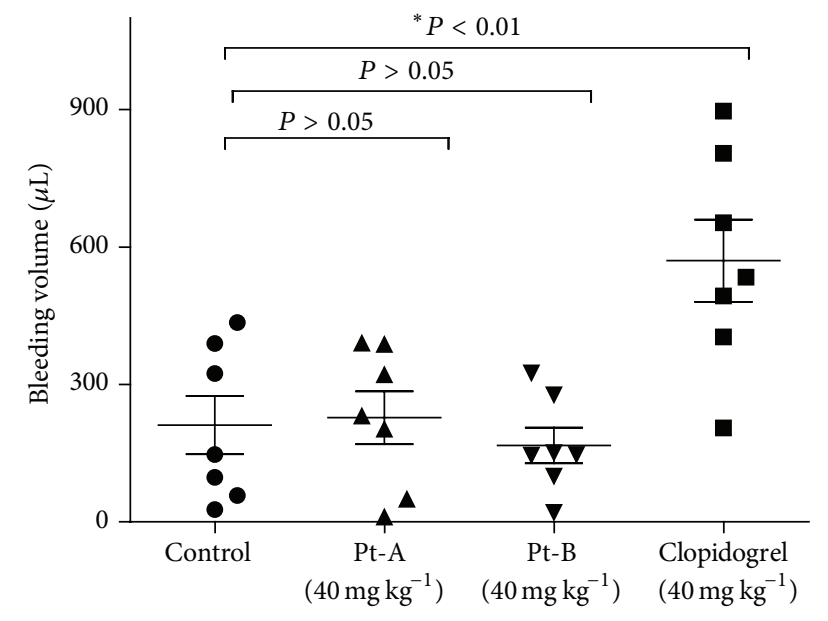

Figure 5: Effects of Pt-A and Pt-B on haemorrhage risks in comparison with clopidogrel. Mice in each group received the corresponding chemicals, and the control group received saline. Each dot represented the bleeding volume of an individual mouse. Means \pm SD of each group were also shown. The data was analyzed with unpaired Student's $t$-test and $P<0.05$ was considered as statistically significant. The significant one was marked with “*”

disease prevention. These two tripeptides could be potential candidates to be implemented as nutraceuticals and pharmaceuticals against thrombosis and its related diseases. In addition, it is expected that this study will develop interests in research and potential applications of snake venom liquor.

\section{Conflict of Interests}

The authors declare that there is no conflict of interests regarding the publication of this paper.

\section{Acknowledgments}

This work was financially supported by the Qianjiang Talents C and D Scheme of Zhejiang Province (QJD1302020) and Zhejiang Province Key Science and Technology Innovation Program (2011R09042-07).

\section{References}

[1] American Diabetes Association, "8. Cardiovascular disease and risk management," Diabetes Care, vol. 38, supplement 1, pp. S49-S57, 2015.

[2] C. H. Hennekens, J. E. Buring, P. Sandercock, R. Collins, and R. Peto, "Aspirin and other antiplatelet agents in the secondary and primary prevention of cardiovascular disease," Circulation, vol. 80, no. 4, pp. 749-756, 1989.

[3] L. He, "A novel snake venom liquor for cardiovascular desease 12 and preparaion method," C.N. 101623484A, 2010.

[4] C. Zhang, X.-D. Yu, Q.-Y. He, H. Li, H.-P. Wen, and J.-Y. Deng, "Animal experimental study on efficacy of Snake-Venom Active wine," Labortory Medicine and Clinic, vol. 7, no. 14, p. 3, 2010.

[5] B. L. Stuart, "The harvest and trade of reptiles at U Minh Thuong National Park, southern Vietnam," Traffic Bulletin, vol. 20, no. 1, pp. 25-34, 2004.
[6] H. Nooren and G. Claridge, Wildlife Trade in Laos: The End of the Game, IUCN-The World Conservation Union, 2001.

[7] C. Y. Koh and R. M. Kini, "From snake venom toxins to therapeutics-cardiovascular examples," Toxicon, vol. 59, no. 4, pp. 497-506, 2012.

[8] S.-H. Lee, Z.-J. Qian, and S.-K. Kim, "A novel angiotensin I converting enzyme inhibitory peptide from tuna frame protein hydrolysate and its antihypertensive effect in spontaneously hypertensive rats," Food Chemistry, vol. 118, no. 1, pp. 96-102, 2010.

[9] Y. Kong, J.-L. Huo, W. Xu, J. Xiong, Y.-M. Li, and W.-T. Wu, "A novel anti-platelet aggregation tripeptide from Agkistrodon acutus venom: isolation and characterization," Toxicon, vol. 54, no. 2, pp. 103-109, 2009.

[10] G. V. R. Born, "Aggregation of blood platelets by adenosine diphosphate and its reversal," Nature, vol. 194, no. 4832, pp. 927929, 1962.

[11] J. Dörffler-Melly, L. A. Schwarte, C. Ince, and M. Levi, "Mouse models of focal arterial and venous thrombosis," Basic Research in Cardiology, vol. 95, no. 6, pp. 503-509, 2000.

[12] H. C. Whinna, "Overview of murine thrombosis models," Thrombosis Research, vol. 122, pp. S64-S69, 2008.

[13] J. Fernández, J. M. Gutiérrez, Y. Angulo et al., "Isolation of an acidic phospholipase $A_{2}$ from the venom of the snake Bothrops asper of Costa Rica: biochemical and toxicological characterization," Biochimie, vol. 92, no. 3, pp. 273-283, 2010.

[14] J. Xiong, W. Fang, W. Fang et al., "Anticoagulant and antithrombotic activity of a new peptide pENW (pGlu-Asn-Trp)," Journal of Pharmacy and Pharmacology, vol. 61, no. 1, pp. 89-94, 2009.

[15] S. Subramaniam, I. Thielmann, M. Morowski et al., "Defective thrombus formation in mice lacking endogenous factor VII activating protease (FSAP)," Thrombosis and Haemostasis, vol. 113, no. 4, pp. 870-880, 2015.

[16] C. Kawecki, N. Hézard, O. Bocquet et al., "Elastin-derived peptides are new regulators of thrombosis," Arteriosclerosis, Thrombosis, and Vascular Biology, vol. 34, no. 12, pp. 2570-2578, 2014.

[17] D. C. I. Koh, A. Armugam, and K. Jeyaseelan, "Snake venom components and their applications in biomedicine," Cellular and Molecular Life Sciences, vol. 63, no. 24, pp. 3030-3041, 2006.

[18] K. M. Lo, S. W. Chen, and T. B. Lo, "Isolation and chemical characterization of small peptides from Formosan snake venoms," Journal of the Chinese Biochemical Society, vol. 2, no. 2, p. 5, 1973.

[19] B. Francis and I. I. Kaiser, "Inhibition of metalloproteinases in Bothrops asper venom by endogenous peptides," Toxicon, vol. 31, no. 7, pp. 889-899, 1993.

[20] I. Maeda, T. Kato, A. Tani, H. Aoyagi, H. Kihara, and M. Ohno, "Characterization of peptides isolated from Trimeresurus flavoviridis and Trimeresurus okinavensis venoms," Bulletin of the Chemical Society of Japan, vol. 66, no. 5, pp. 1569-1571, 1993.

[21] K.-F. H. Huang, C.-C. Hung, S.-H. Wu, and S.-H. Chiou, "Characterization of three endogenous peptide inhibitors for multiple metalloproteinases with fibrinogenolytic activity from the venom of Taiwan Habu (Trimeresurus mucrosquamatus)," Biochemical and Biophysical Research Communications, vol. 248, no. 3, pp. 562-568, 1998. 


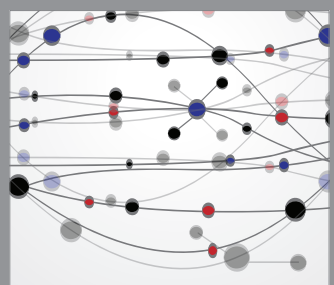

The Scientific World Journal
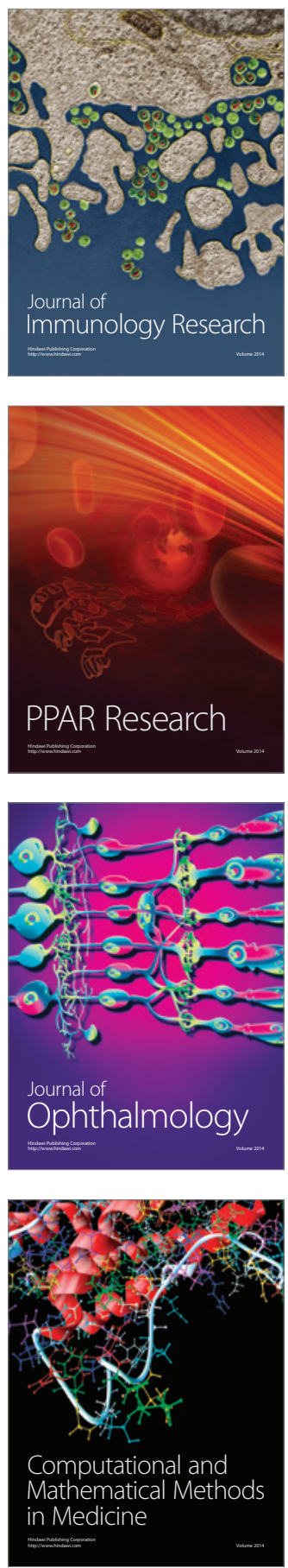

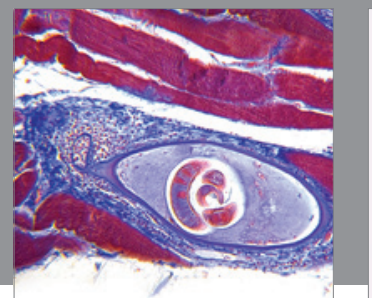

Gastroenterology

Research and Practice
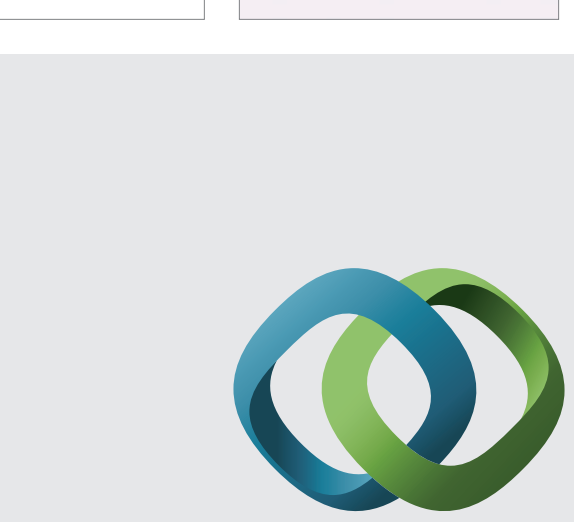

\section{Hindawi}

Submit your manuscripts at

http://www.hindawi.com
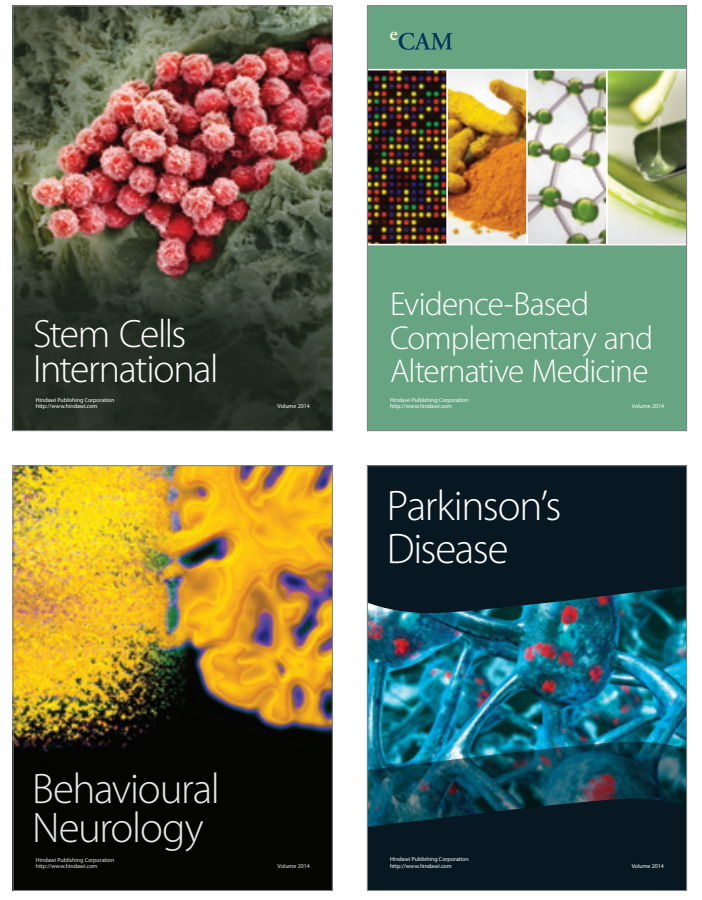
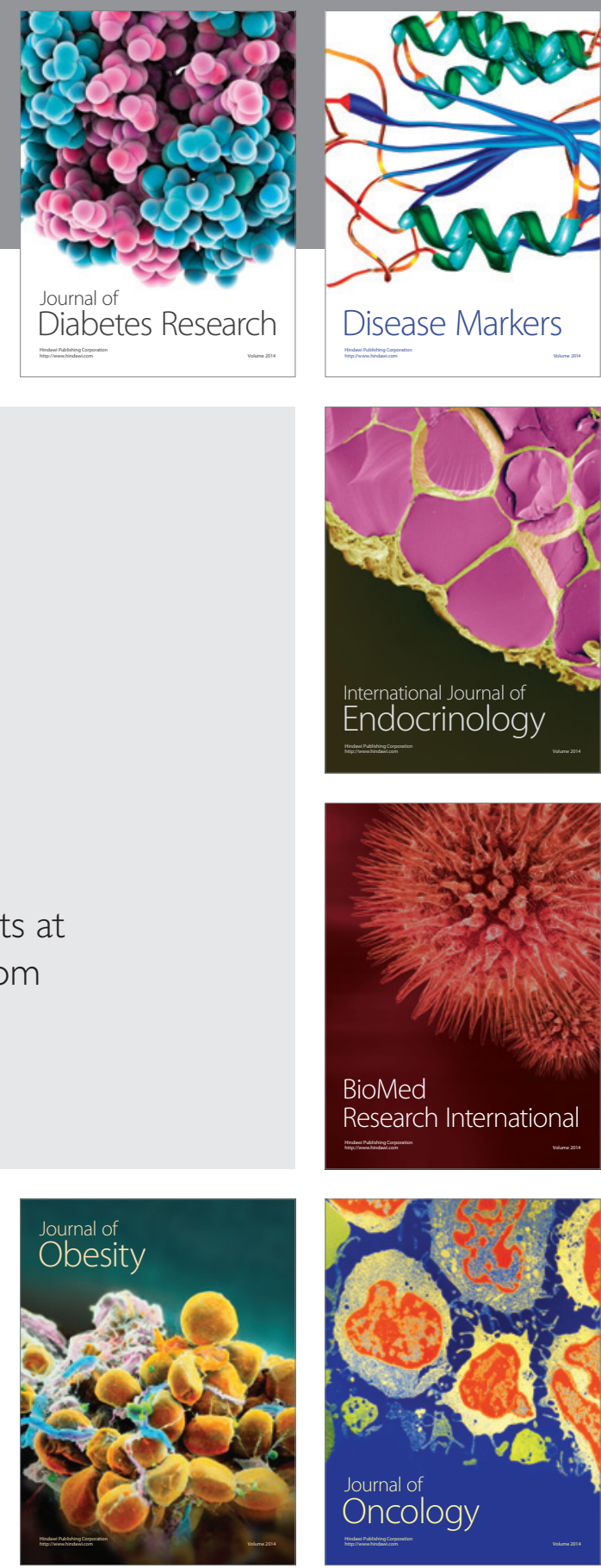

Disease Markers
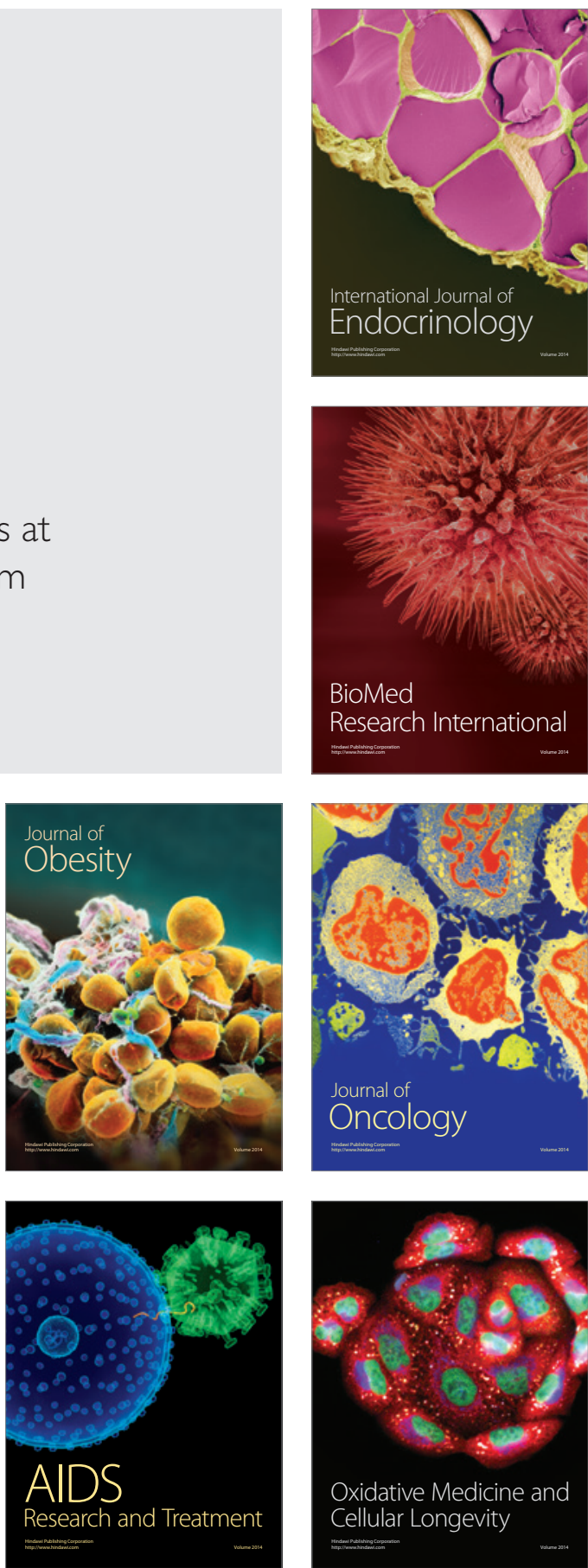